\title{
POSSIBILITIES FOR ENERGY RECOVERY IN THE TREATMENT OF EFFLUENTS FROM DISTILLERY AND FEEDLOT OPERATIONS**
}

\begin{abstract}
Result of pilot and full-scale studies on anaerobic digestion in flow-through and sludge-recycle modes are reported. Efficiency of biogas production and energy conversion into electrical power is calculated to show that for feedlot effluents such as piggery farms the recovered energy is sufficient to cover the energy requirements of the whole farm in the most severe (Italy) conditions.
\end{abstract}

\section{INTRODUCTION}

Effuents from alcohol distilleries and animal feedlots may represent a serious problem for the quality of the environment if they are discharged into surface waters without adequate purification treatment. On the other hand, the application of conventional purification methods to meet the standards set by law for the discharge of such effluents would make the costs to producers prohibitive. The application by R.P.A. of the anaerobic digestion to treatment of these effluents allows the utilization of the biogas produced during the purification process and enables the producer to reduce treatment costs and, in many cases, also production costs.

\section{DISTILLERY WASTEWATERS}

Wastewaters from distillery operations represent one of the most difficult types of effluents to be purified due to their distinctive chemical and physical properties, namely: high content of rapidly biodegradable organic matter (in some cases COD exceeds 100,000 $\mathrm{mg} \mathrm{O}_{2} / \mathrm{dm}^{3}$ ); high content of suspended or colloidal solids denoted by SS; high tempera-

* R.P.A. - Risorse Ambientali, 06074 Perugia, Fontana, Strada del Colle, Italy.

** The paper was presented at the conference on Energetics and Technology of Biological Elimination pf Wastes, Roma, 17-19 October 1979. 
ture, particularly as concerns spent slops from distillation columns, which may even exceed $90^{\circ} \mathrm{C}$ at discharge.

Tab. 1 lists the mean values of the major parameters pertaining to distillery slops according to the raw material processed. As the table shows, slop composition varies greatly depending on the raw material processed. Additional variations may be caused by the type of equipment and techniques used in the various phases of preparation, fermentation and distillation.

Table 1

Average characteristics of distillery slops

Przeciętne właściwości wywarów gorzelniczych

\begin{tabular}{lcccccc}
\hline \multicolumn{1}{c}{ Parameter } & Peaches & Apples & Dregs & Molasses & Wine & Potatoes \\
\hline $\mathrm{COD}\left(\mathrm{g} \mathrm{O}_{2} / \mathrm{dm}^{3}\right)$ & 100 & 85 & 33 & 98 & 25 & 90 \\
$\mathrm{BOD}\left(\mathrm{g} \mathrm{O}_{2} / \mathrm{dm}^{3}\right)$ & 40 & 38 & 16 & 62 & 14 & 65 \\
$\mathrm{SS}\left(\mathrm{g} / \mathrm{dm}^{3}\right)$ & 15 & 15 & 10.8 & 2.5 & 1.5 & 17
\end{tabular}

\subsection{ANAEROBIC TREATMENT AND BIOLOGICAL OXIDATION}

Over the past several years, the R.P.A. conducted highly successful experiments with the anaerobic treatment of raw effluents from distilleries and the subsequent biological oxidation of the effluent from the anaerobic process. In 1974, systematic experimentations were begun with the anaerobic treatment of various distillery effluents, first conducting tests in a laboratory-scale pilot plant and, subsequently, verifying the results obtained in two industrial-scale plants.

The experimental plant ran on the basis of a continuous loading of slops adequately supplemented with nutrients to obtain a ratio $C O D: N: P=100: 1.5: 0.2$. This ratio is considerably lower than that required in a biological oxidation process, due to the fact that in the anaerobic process the production of biological solids is markedly lower; it varies between 0.05 and $0.25 \mathrm{~kg}$ of solids produced per $\mathrm{kg}$ of stabilized COD, depending on the substrate used.

The settled sludge in the experimental plant was recycled in such a way that the average sludge age be not less than 10 days, whereas the hydraulic retention time was in somg cases considerably shorter. Temperature was kept constant at $35^{\circ} \mathrm{C}$ by means of a heat control system. The gas produced was measured and periodically analyzed to determine its composition and calorific value. The results obtained are summarized in tab. 2 .

\subsubsection{FRUIT SLOPS (PEACHES AND AṔPLES)}

The slops treated were supplied by the Dalmonte Distillery of Cotignola (Ravenna) and the M. G. Distillery of Voltana di Lugo (Ravenna). Their concentration differed depending on the types of distillation columns used in the two plants. Digestion tests on both types of slops indicated an increase in acidity which had to be corrected by means of 
Results obtained with anaerobic treatment

Wyniki uzyskane podczas beztlenowego oczyszczania

$\begin{array}{lccccc}\begin{array}{c}\text { Type } \\ \text { of slops }\end{array} & \begin{array}{c}\text { COD at } \\ \text { leaching } \\ \mathrm{g} / \mathrm{dm}^{3}\end{array} & \begin{array}{c}\text { COD at } \\ \text { discharge } \\ \mathrm{g} / \mathrm{dm}^{3}\end{array} & \begin{array}{c}\text { Reten- } \\ \text { tion } \\ \text { time } \\ \text { (days) }\end{array} & \begin{array}{c}\text { Stabilization } \\ \text { efficiency } \\ \%\end{array} & \begin{array}{c}\text { Purification } \\ \text { efficiency } \\ \%\end{array} \\ \text { Peaches } & 85 & 4.2 & 7 & 75 & 95 \\ \text { Apples } & 35 & 2.0 & 5 & 75 & 94 \\ \text { Wine } & 20 & 1.6 & 4 & 71 & 92 \\ \text { Dregs } & 28 & 2.2 & 10 & 67 & 92 \\ \text { Molasses } & 100 & 15.0 & 12 & 78 & 85\end{array}$

initial neutralization of the slops with calcium hydroxide. A greater stability of the process was obtained by addition of sodium bicarbonate which, contrary to lime, gives rise to the formation of soluble alkaline compounds preventing the formation of free volatile acids. The minimum hydraulic retention time tested in stable conditions was 7 days for the more concentrated slops $\left(\mathrm{COD}=85,000 \mathrm{mg} \mathrm{O} / \mathrm{dm}^{3}\right)$ and 5 days for more tiluted type $\left(\mathrm{COD}=35,00 \mathrm{mg} \mathrm{O} \mathrm{O}_{2} / \mathrm{dm}^{3}\right)$. Treatment efficiency after sedimentation was approximately $95 \%$ with COD values for the effluent amounting, respectively, to 4,200 and $2,00 \mathrm{mg}$ $\mathrm{O}_{2} / \mathrm{dm}^{3}$. Stabilization efficiency was $75 \%$ with a production of biogas equal roughly to $470 \mathrm{dm}^{3}$ per $\mathrm{kg}$ of COD removed. The calorific value of the gas produced was $5,600 \mathrm{Kcal} / \mathrm{m}^{3}$ with a methane content of $67 \%$ and a carbon dioxide content close to $33 \%$.

\subsubsection{WINE SLOPS}

Wine slops with an average COD of about $20,000 \mathrm{mg} \mathrm{O}_{2} / \mathrm{dm}^{3}$ were used with particularly high efficiency rates, even at low hydraulic retention times. Stability was obtained at time as short as three days, but only when sodium bicarbonate was added. With a hydraulic retention time of 4 days and slops initially neutralized with calcium hydroxide, the efficiency rates of $92 \%$ were obtained after sedimentation, with effluents averaging $1,600 \mathrm{mg} \mathrm{O} / \mathrm{dm}^{3}$ COD. Efficiency rates in biogas production were comparable to those obtained with fruit slops.

\subsubsection{DETARTARIZED DREGS}

Dregs slops subjected to detartarization contain substantial quantities of calcium sulphate, which, during the process of anaerobic digestion, give rise to the formation of hydrogen sulphide creating an environment toxic to the anaerobic microorganisms. This difficulty was overcome in the laboratory by recycling biogas treated with iron oxide.

With this system, using liquid dregs with an average COD of $28,000 \mathrm{mg} \mathrm{O}_{2} / \mathrm{dm}^{3}$, stabilization efficiency rates of $67 \%$ and purification efficiency rates of $92 \%$ ater sedimentation were obtained. The average COD of the effluent was $2,200 \mathrm{mg} \mathrm{O} / \mathrm{dm}^{3}$. Hydraulic retention time was 10 days. 


\subsubsection{MOLASSES SLOPS}

Molasses slops contain substantial amounts of dissolved salts with significant quantities of sulphates, which - as described above - can create toxic conditions in the reaction environment. However, since the initial COD of molasses slops is particularly high, the specific production of biogas per $\mathrm{m}^{3}$ is so large that gas itself is sufficient to exercise a vigorous purging action on the hydrogen sulphide, reducing the concentration of dissolved acid below the threshold of toxicity.

Laboratory tests were carried out using raw slops from cane molasses with an average COD of $100,000 \mathrm{mg} \mathrm{O}_{2} / \mathrm{dm}^{3}$. The retention time required for operational stability was 11 days with stabilization efficiency rates of $78 \%$ and purification rates of $85 \%$ after sedimentation.The quantity of gas produced was roughly $500 \mathrm{dm}^{3} / \mathrm{kg}$ COD-stabilized with a calorific value of $5,800 \mathrm{Kcal} / \mathrm{m}^{3}$. No toxicity effects were observed. As with all other types of effluent, the effluent from the anaerobic process, which retained a COD of roughly $15,000 \mathrm{mg} \mathrm{O}_{2} / \mathrm{dm}^{3}$ and a BOD of 4,500, was subjected to biological oxidation tests simulating treatment in aerated ponds. While in other cases the biodegradability of the treated effluents was almost complete, in the case of molasses slops a final effluent was obtained having a residual BOD of roughly $120 \mathrm{mg} \mathrm{O} / \mathrm{dm}^{3}$, but with a $\mathrm{COD}$ at levels between 5,000 and $6,500 \mathrm{mg} \mathrm{O} \mathrm{O}_{2} / \mathrm{dm}^{3}$, together with an intense dark colour.

\subsection{FULL SCALE PLANTS}

At the beginning of 1977, the R.P.A. designed a first full-scale purification plant for the Del Bosco Distillery in Voltana di Lugo (Ravenna), which included a 1,200 $\mathrm{m}^{3}$ anaerobic digester and a $6,000 \mathrm{~m}^{3}$ aerated pond.

The raw slops flow into an equalization tank where it is possible to correct $\mathrm{pH}$ and control the temperature of the slops, as well as add nutrients as required. The discharge from the equalization tank is pumped into the anaerobic digester, thermostatically regulated at $35^{\circ} \mathrm{C}$ and stirred. It proved necessary to install a degasifier at the outflow of the digester in order to improve the settleability of the sludge, which is generally recycled and only periodically filtered and disposed off. The clarified effluent is then pumped into the oxidation pond, from which it flows by gravity into a sedimentation basin and is then discharged. For more than a year the plant has been used to treat slops from dregs, wine, fruit and, most recently, potatoes and carob.

The plant has worked perfectly, producing an effluent from the anaerobic treatment with COD varying between 1,200 and $2,500 \mathrm{mg} \mathrm{O}_{2} / \mathrm{dm}^{3}$, further reduced, after biological oxidation, to values between 150 and $300 \mathrm{mg} \mathrm{O} / \mathrm{dm}^{3}$. During the period in which dregs were being processed, it was decided to replace the calcium sulphate used in the process of extraction of the tartaric acid with calcium chloride. The increased cost of extraction is compensated by the lower purification costs. At present, part of the biogas produced is used to heat a cylindrical oven designed to dry by-products of the distillery operations, which are then sold as animal feed. The sludge for disposal, as well as being in extremely small quantities, is easily filterable without the need for additional conditioning agents. 
With the distillery's old chemical-physical plant, the sludge was filtered continuously, whereas, with the new system, this operation is carried out only periodically, the sludge being continually recycled in the digester and discharged in part only when it reaches levels of concentration that could compromise settleability.

Subsequently, a second plant was designed for the M. G. Distillery in Voltana di Lugo, which produces alcohol through the distillation of fruit. The plant is made up of a $2,00 \mathrm{~m}^{3}$ digester, thermostated at $35^{\circ} \mathrm{C}$ and stirred, capable of treating $200 \mathrm{~m}^{3} / \mathrm{d}$ of slops. The average COD of the effluent is $50 \mathrm{~g} \mathrm{O}_{2} / \mathrm{dm}^{3}$ and the production of biogas amounts to roughly $3,500 \mathrm{~m}^{3}$. The distillery is now installing a $300 \mathrm{~m}^{3}$ capacity gasometer to permit the recovery and immediate use of the biogas produced. The gas will be used to produce steam in a boiler heated by a burner fueled either with biogas or with fuel oil. The use of the biogas should permit the distillery to reduce its present fuel oil consumption by one-third.

\section{FEEDLOTS}

Animal feedlots are another sector where energy recovery at various levels is possible. The greater part of the feedlots in our country operate according to an open cycle as synthetically ilustrated in fig. 1. In other words, the feedlot purchases from the outside all the energy it consumes in its various operations and, to a greater or lesser extent and in most cases in their entirety, its raw materials, producing in turn, as its only marketable

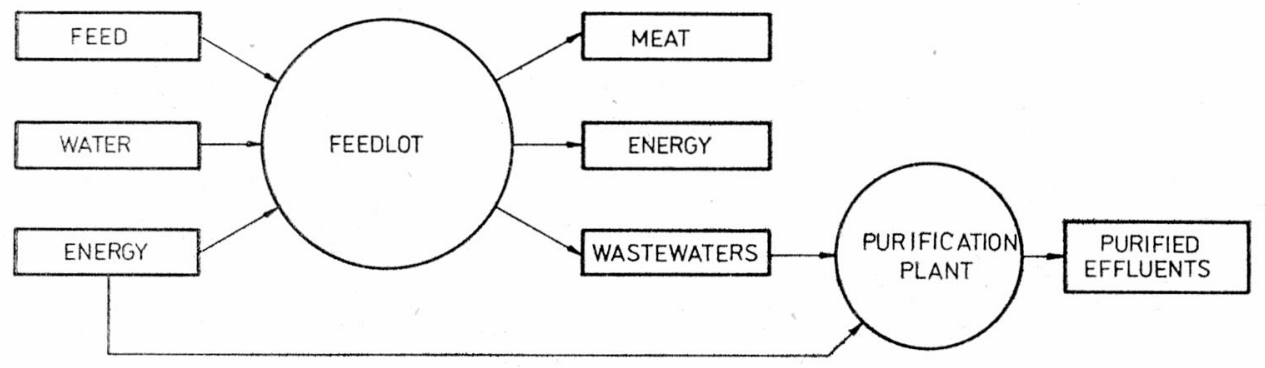

Fig. 1. Layout of an open-cycle feedlot

Rys. 1. Układ fermy w cyklu otwartym

mroduct, meat. By-products, generally not reused, include low temperature heat and the wastewaters produced in the feedlot, which are either discharged untreated into surface waters, causing serious damage to the natural environment or, in compliance with the law, treated by conventional purification methods before discharge, with a substantial consumption of energy.

The additional energy consumption, necessary for the purification of wastewaters in compliance with the law, has further jeopardized the cost-returns ratio of feedlot operations. Rising costs in recent years as concerns feed $\left(87,000 \mathrm{~L}^{*} / \mathrm{t}\right.$ in $1973,220,00 \mathrm{~L} / \mathrm{t}$ in 1979),

* $\mathrm{L}$ denotes lire. 
fuel oil $(18 \mathrm{~L} / \mathrm{kg}$ in $1973,240 \mathrm{~L} / \mathrm{kg}$ in 1979) and electricity $(9 \mathrm{~L} / \mathrm{K} w h$ in $1973,34 \mathrm{~L} / \mathrm{Kwh}$ in 1979) have, in fact, not been offset by a proportional increase in the price of meat (700 $\mathrm{L} / \mathrm{kg}$ in $1975,1,100 \mathrm{~L} / \mathrm{kg}$ in 1979). If we add the fact that spiralling energy costs are destined to widen this imbalance between costs and returns, it is clear that feedlots in general, and swine and poultry farms in particular, will be forded to modify substantially and rationalize their operations in order to restore their profit margins.

To make these concepts more comprehensible, the feedlot's input (feed and energy requirements) and output (meat, lost energy and waste products) flows must be quantified.

\subsection{ENERGY REQUIREMENTS}

All the calculations used in this report are based on a farm running a swine feedlot with an average population of 8,600 head (corresponding to a live weight of 600 tons) and a poultrylot of 45,000 laying hens (corresponding to a live weight of 90 tons).

The energy requirements of the farm include the electricity used for lighting and running motors and the fuel oil used for heating farrowing and weaning pens and air-conditioning fattening pens and poultry barns.

Energy consumption naturally varies over the year in relation to environmental temperature conditions. In 1978, the farm consumed over 300 tons of fuel oil with a calorific value of $10,200 \mathrm{Kcal} / \mathrm{kg}$, or the equivalent of $3,000 \times 10^{6} \mathrm{Kcal}$, and $560,000 \mathrm{Kwh}$ of electricity, equal to $480 \times 10^{6} \mathrm{Kcal}$ (tab. 3). Total energy consumption for one year was there-

T a ble 3

Feedlot energy requirements

Zapotrzebowanie energetyczne fermy

\begin{tabular}{lcc}
\hline \multicolumn{1}{c}{ Parameter } & Unit & Value \\
\hline Fuel oil consumption & $\mathrm{t} / \mathrm{a}$ & 305 \\
Calorific value & $\mathrm{Kcal} / \mathrm{kg}$ & 10,200 \\
Thermal energy consumption & $\mathrm{Kcal} / \mathrm{a}$ & $3,111 \times 10^{6}$ \\
$\begin{array}{l}\text { Average daily thermal } \\
\quad \text { energy consumption }\end{array}$ & $\mathrm{Kcal} / \mathrm{d}$ & $8.5 \times 10^{6}$ \\
$\begin{array}{l}\text { Electricity consumption } \\
\text { Average daily electricity } \\
\quad \text { consumption }\end{array}$ & $\mathrm{Kwh} / \mathrm{a}$ & 559,300 \\
& $\mathrm{Kwh} / \mathrm{d}$ & 1,532 \\
& &
\end{tabular}

Population: 8,600 pigs corresponding to $600 \mathrm{t}$ of meat: 45,000 hens corresponding to $90 \mathrm{t}$ of meat.

fore roughly $3,560 \times 10^{6} \mathrm{Kcal} / \mathrm{a}$, meaning a daily average consumption of approximately $10 \times 10^{6} \mathrm{Kcal}$. The diagram in fig. 2 traces the variations in fuel oil consumption over the year 1978, variations which obviously reflect the latitude where the farm is located and the annual climatic conditions registered in the area. 
Fig. 2. Energy requirements (fuel oil) in 1978

Rys. 2. Zapotrzebowania energii (paliwo olejowe) w 1978 r.

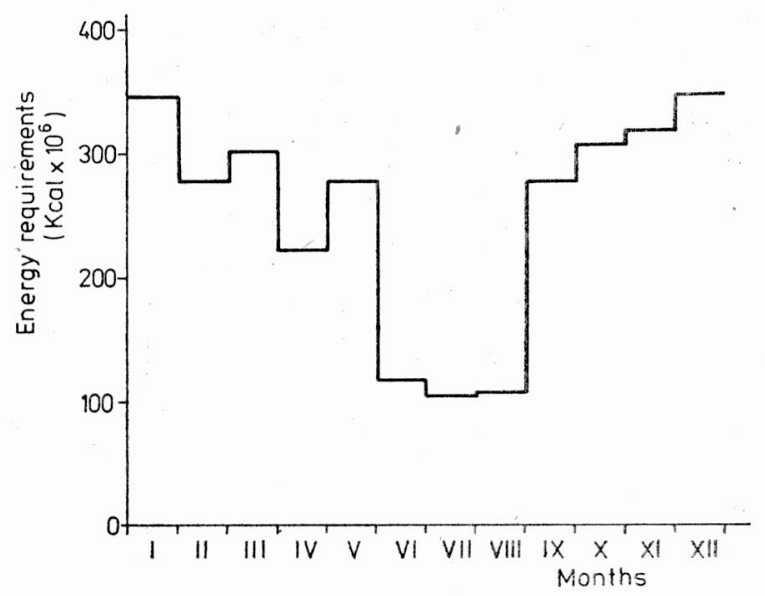

\subsection{FEED REQUIREMENTS}

Tab. 4 synthesizes the feed requirements of the feedlot in terms of total weight and principal characteristics, including protein content and total and digestible energy content.

Table 4

Feed requirements

Wymogi paszowe

\begin{tabular}{|c|c|c|c|}
\hline Parameter & Unit & Pigs & Hens \\
\hline Feed & $t / d$ & 24 & 5.5 \\
\hline Digestibility & $\%$ & 77 & 67 \\
\hline Protein content & $\%$ & 20 & 18.5 \\
\hline Protein consumption & $t / d$ & 4.8 & 10.20 \\
\hline Total energy content & $\mathrm{Kcal} / \mathrm{kg}$ & 4,200 & 4,200 \\
\hline Digestible energy content & $\mathrm{Kcal} / \mathrm{kg}$ & 3,400 & 2,700 \\
\hline Unused energy content & $\mathrm{Kcal} / \mathrm{kg}$ & 800 & 1,300 \\
\hline Quantity of unused energy & $\mathrm{Kcal} / \mathrm{d}$ & $19,2 \times 10^{6}$ & $7.2 \times 10^{6}$ \\
\hline
\end{tabular}

It is interesting to note that both pigs and chickens, being monogastric animals, are poor digesters. Thus a substantial part of the energy content of their food $(23 \%$ for pigs and $33 \%$ for chickens) passes unaltered into wastewaters. 


\subsection{WASTEWATER CHARACTERISTICS}

The feedlot under consideration produces a daily quantity of wastewater, the quantitative and qualitative characteristics of which are outlined in tab. 5.

\section{Table 5}

Daily production of feedlot wastewaters

Dzienna produkcja ścieków z fermy

\begin{tabular}{lccc}
\hline \multicolumn{1}{r}{ Index } & Unit & Pigs & Hens \\
\hline Raw waste & & & \\
Total solids & $\mathrm{t} / \mathrm{d}$ & 30 & 5.9 \\
Nitrogen & $\mathrm{t} / \mathrm{d}$ & 4.1 & 1.5 \\
Phosphorus & $\mathrm{kg} / \mathrm{d}$ & 230 & 85 \\
Potassium & $\mathrm{kg} / \mathrm{d}$ & 45 & 30 \\
Energy content & $\mathrm{kg} / \mathrm{d}$ & 47 & 26 \\
& $\mathrm{Kcal} / \mathrm{d}$ & $\mathbf{1 9 . 2 \times 1 0 ^ { 6 }}$ & $7.2 \times 10^{6}$
\end{tabular}

Population: 8,600 pigs corresponds to $600 \mathrm{t}$ of meat; 45,000 hens corresponds to $90 \mathrm{t}$ of meat.

As can be seen from tab. 5, these wastewaters (whose daily volume depends on the amount of water used to flush the pens, in the case under consideration, roughly $200 \mathrm{~m}^{3} / \mathrm{d}$ ) contain substantial quantities of organic substances, nitrogen, phosphorus and potassium together with a significant thermal content $\left(26.4 \times 10^{6} \mathrm{kcal} / \mathrm{d}\right)$ originating from the organic substances not assimilated by the animals. Or, given their high energy content and the amount of fertilizing elements they contain, they can be profitably reused, as we shall illustrate below.

\subsection{ENERGY FLOWS FROM PENS}

To increase productivity, farrowing and weaning pens for pigs and poultry barns must be kept at controlled temperature and humidity conditions. Similarly, to maximalize daily weight increase, fattening pens must be kept ventilated. The immission of air, heated during the cold season by burning fuel oil, and the extraction of an equal quantity of used air from the pens means that all the heat generated by the animals is lost into the atmosphere rather than being reused. The quantity of heat thus lost is shown in tab. 6 .

\subsection{THE “ADVANCED” FEEDLOT}

A feedlot operating on an "advanced" basis must seek to satisfy its energy and feed requirements at least in part by recovering as much as possible from its own output flows (lost energy and wastewaters). 
Energy requirements and recoverable heat

Zapotrzebowanie energii i ciepło możliwe do odzysku

Source

a. Poultry barns

Heating plant capacity

Heat produced by animals

b. Swine feedlot

Heating plant capacity

Heat produced by animals

c. Anaerobic digester

Heating plant capacity

Heat from digested effluent
Quantity of heat lost

In this report, we shall illustrate the techniques and equipment installed or being installed by the R.P.A. and the Rodon Impianti, with whom the author collaborates closely, at the farm described above.

The aim was to reuse the output flows from the feedlot (wastewaters and energy) in order to reduce the input flows (energy and feed requirements) to the greatest possible extent. In pratice, we have sought to achieve a use cycle of the sort illustrated in the diagram in fig. 3 .

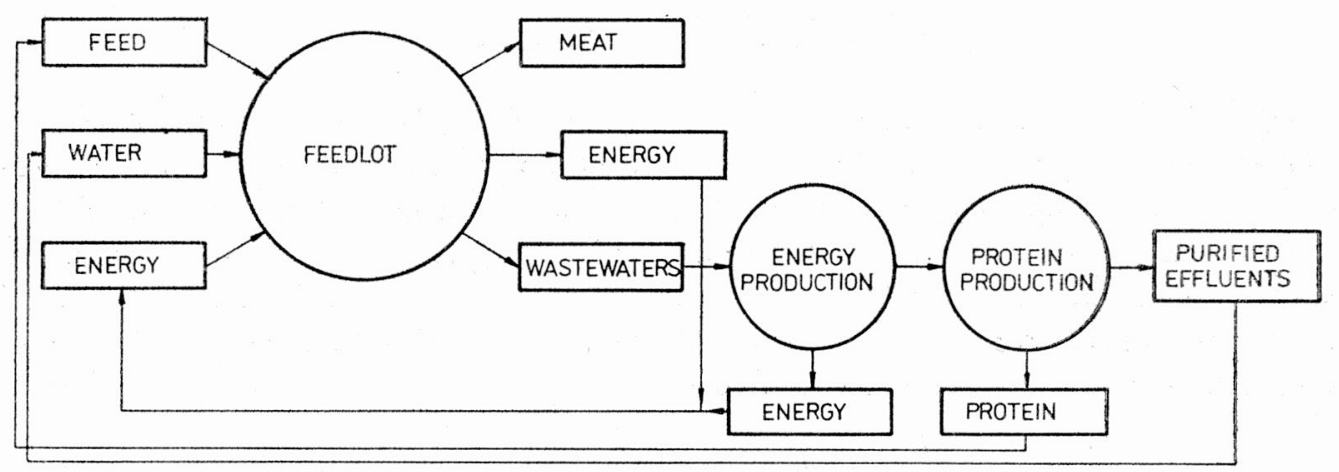

Fig. 3. Recovery system in closed-cycle feedlot

Rys. 3. System odzysku fermy w cyklu zamkniętym

\subsection{ANAEROBIC DIGESTION OF WASTEWATERS}

If only part of the energy content $\left(26.4 \times 10^{6} \mathrm{Kcal} / \mathrm{d}\right)$ of the wastewaters were recovered, the energy generated through biogas production in the anaerobic digestion would cover the average daily energy requirements of the feedlot. 
The process of anaerobic digestion is conducted in closed, insulated reactors heated to $35-37^{\circ} \mathrm{C}$ and stirred. Under these conditions, it allows to gasify roughly $50-70 \%$ of the organic substance contained in the wastes and thus to recover, through the biogas produced, an equivalent percentage of the initial thermal content present in the wastewaters. In the feedlot under consideration the digestion process takes place in two digesters of $1,000 \mathrm{~m}^{3}$ each, built of steel, insulated and stirred by means of the insufflation of compressed biogas. The hydraulic retention time is roughly 10 days, whereas sludge age can be regulated at convenience by recycling the settled sludge. Under these conditions the efficiency rates shown in tab. 7 are obtainable.

\section{Table 7}

Efficiency of anaerobic digestion

Wydajność fermentacji beztlenowej

\begin{tabular}{ll}
\multicolumn{1}{c}{ Parameter } & \multicolumn{1}{c}{ Efficiency } \\
\hline $\begin{array}{l}\text { Heat content of wastes } \\
\text { at loading }\end{array}$ & $26.4 \times 10^{6} \mathrm{Kcal} / \mathrm{d}$ \\
Stabilization efficiency & $50 \%$ \\
Calorific value of biogas & $5,600 \mathrm{Kcal} / \mathrm{m}^{3}$ \\
Biogas produced & $2,400 \mathrm{~m}^{3} / \mathrm{d}$ \\
Recovered heat content & $13.4 \times 10^{6} \mathrm{Kcal} / \mathrm{d}$
\end{tabular}

\subsection{USE OF THE BIOGAS}

The biogas produced is used to run 11 Fiat TOTEM (Total Energy Module) units. The TOTEM is composed of a Fiat 127 engine, burning biogas in this case, and an asynchronous electric motor capable of emitting electricity and heat at the same time. The Fiat system was chosen because its overall performance is superior to that obtainable with conventional systems for the production of electricity and heat. Tab. 8 illustrates the basic performance properties of the TOTEM as supplied by Fiat. Tab. 9 shows the energy obtainable when all the biogas produced is used to run TOTEM units.

\subsubsection{USE OF THE ENERGY PRODUCED WITH BIOGAS}

In a first phase, the electricity and heat produced by the TOTEM units will be used in part to satisfy current power consumption ( $85 \mathrm{~kW}$ of installed power), while the excess will be used in the anaerobic digestion plant $(24 \mathrm{~kW})$ and to satisfy contingent power needs (irrigation, etc.).

The heat generated in the thermal circuit will be used in part to heat the digester and in part in the poultry barns. The excess, particularly in the summer months, will have to be dissipated without productive utilization.

In a later phase, however, when the digestion plant is running at full capacity, the use of heat pumps is planned, as already successfully experimented in another division of the 
TOTEM basic performance

Podstawowe parametry systemu TOTEM przetwarzającego gaz na energię elektryczną

Parameter

127 engine (biogas)

fuel consumption

thermal energy input

mechanical energy output

thermal energy output

$380 \mathrm{~V}$ 3-phase alternator

electric energy output

thermal energy output

Total balance

energy input

electric energy output

thermal energy recovered

total losses
Basic performance

$15 \mathrm{kw}(\eta=90 \%)$

$1.5 \mathrm{kw}$

$1,300 \mathrm{Kcal} / \mathrm{h}$

$50,000 \mathrm{Kcal} / \mathrm{h}$

$13,000 \mathrm{Kcal} / \mathrm{h}$

$33,000 \mathrm{Kcal} / \mathrm{h}$

$4,000 \mathrm{Kcal} / \mathrm{h}$

Table 9

Energy obtainable from biogas using TOTEM. units

Energia moźliwa do uzyskania z biogazu przy użyciu jednostek

TOTEM

\begin{tabular}{lc}
\hline \multicolumn{1}{c}{ Energy } & Amount of energy \\
\hline Thermal energy of biogas & $13.4 \times 10^{6} \mathrm{Kcal} / \mathrm{d}$ \\
Thermal energy & $5.6 \times 10^{5} \mathrm{Kcal} / \mathrm{h}$ \\
Thermal energy absorbed & $5 \times 10^{4} \mathrm{Kcal} / \mathrm{h} / \mathrm{unit}$ \\
No. of TOTEM units working & 11 \\
Thermal energy recovered & $3.6 \times 10^{5} \mathrm{Kcal} / \mathrm{h}$ \\
& $8.7 \times 10^{6} \mathrm{Kcal} / \mathrm{d}$ \\
Electric power output & $165 \mathrm{~kW}$ \\
Electric energy output & $3,960 \mathrm{kWh} / \mathrm{d}$
\end{tabular}

same farm (rabbits) and in many other sectors by the Rondon Impianti. The electricity produced by the TOTEMS will then be used primarily to run the electric motors of the heat pumps, which will recycle the thermal energy produced in the various parts of the feed. lot. This, together with the heat recovered from the thermal circuit of the TOTEMS, will make the entire complex self-sufficient even in periods of the heaviest energy consumption, as shown in tab. 10.

\subsection{TREATMENT OF WASTEWATERS FROM ANAEROBIC DIGESTION}

The waters discharged from the anaerobic digester will be purified by putting them through a system of lagoons consisting of two anaerobic ponds followed by a third facultative pond. The waters thus purified can be reused for flushing the pens. In the final 
Energy balance of closed-cycle feedlot

Bilans energetyczny fermy w cyklu zamkniętym

Present energy requirements in heaviest month Heating plant capacity

for poultry barns

for swine pens

Utilization factor in heaviest month

Heating digester in winter months

SWINE PENS

$\varepsilon$ theoretical $=\frac{273+35}{30}=10$ temp. cond. $=35^{\circ} \mathrm{C}$

$\varepsilon$ real $=7.5$

$\mathrm{kW}$ pump $=\frac{4000,000}{860 \times 7.5}=62$

$\mathrm{kW}$ accessories $=16$

$\mathrm{kW}$ total $\simeq 78$

\section{POULTRY BARNS}

$\mathrm{kW}$ pump $=0$

$300,000 \mathrm{Kcal} / \mathrm{h}$ from TOTEMS

$\mathrm{kW}$ accessories $=15$ used

$\mathrm{kW}$ total $=15$

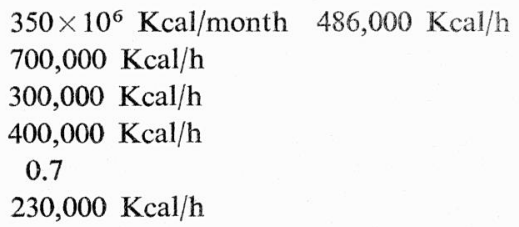

\section{DIGESTER}

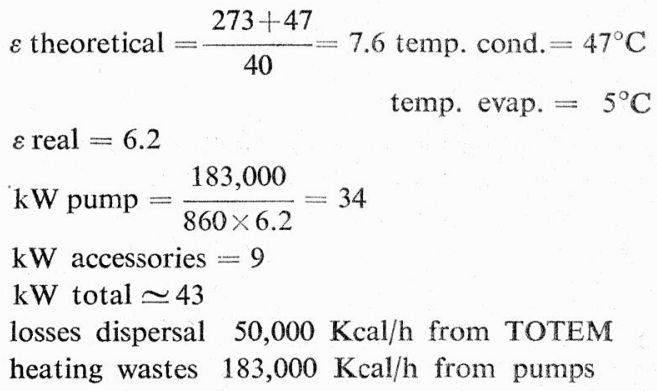

$\mathrm{kW}$ digest. plant $=\frac{24}{160}$

aerobic lagoon, water hyacinths can be grown from May to October. The depurative efficiency of this plant has been amply documented in literature and confirmed in tests run by the R.P.A. in experimental ponds.

Fig. 4 shows the ammonia content in one of the R.P.A. ponds over the month of June where nitrogen being almost completely eliminated, the nitric ion never appears in significant quantities.

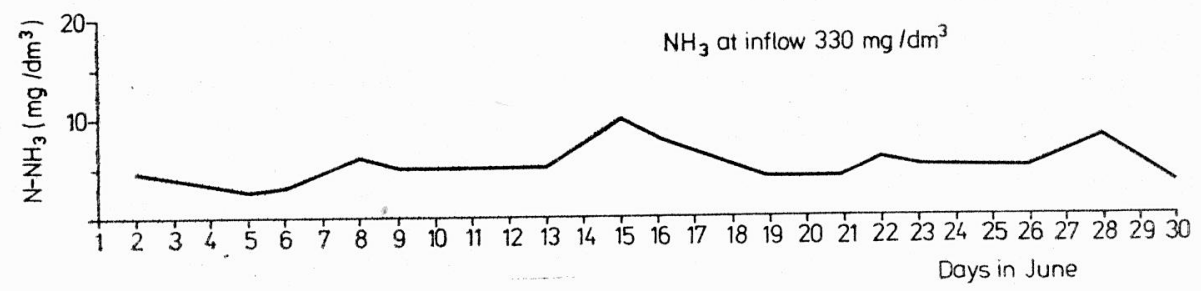

Fig. 4. Ammonia nitrogen in the hyacinth lagoon effluent

Rys. 4. Azot amonowy w odpływie ze zbiornika hiacyntowego do przetrzymywania osadów 
The hyacinth, produced as much as 90 tons of dry weight per hectar per season if properly supplemented, can be reused in the preparation of feed, since it is particularly rich in protein. Systematic tests on the nutrition of swine with fodder containing water hyacinths are being conducted in another feedlot. The results will be available in the course of the year.

\section{CONCLUSIONS}

Experiments carried out in the sector of distilleries and feedlots have shown not only that the purification of effluents need not constitute a technical and financial problem, but that the effluents themselves can be made a source of energy in sufficient quantitites to reduce fuel oil consumption to a significant degree.

In the case of feedlots in particular, it is possible, through the production of biogas to produce electrical power and to apply heat pumps, to make operations selfsufficient even in periods of the heaviest energy consumption.

\section{MOŻLIWOŚCI ODZYSKU ENERGII W PROCESIE OCZYSZCZANIA ŚCIEKÓW Z GORZELNI I FERM PRZEMYSŁOWYCH}

Przedstawiono wyniki badań pilotowych i w pełnej skali beztlenowej fermentacji ścieków w układzie przepływowym i recyrkulacji osadu. Wyliczona efektywność produkcji biogazu i przetwarzania na energię elektryczną wykazała, że odzysk energii ze ścieków, np. z wielkoprzemysłowych tuczarni, wystarcza na pokrycie potrzeb całej fermy w najsurowszych warunkach klimatycznych Włoch.

\section{ENERGIEGEWINNUNG AUS ABWÄSSERN AUS BRENNEREIEN UND ZUCHTBETRIEBEN}

Dargestellt werden Ergebnisse aus einer Versuchsanlage und aus einer Kläranlage im technischen Maßstab mit Faulkammern, worin die Abwässer einer Brennerei und einer Schweine- und Geflügelfarm ausgefault wurden. Der Abbau des $\mathrm{BSB}_{5}$ und des CSB war größer als $90 \%$ bei einer Verweilzeit von $<10 \mathrm{~d}$ und bei Abwasserrückführung von hoch konzentrierten Abflüssen. Besonders zufriedenstellend waren die Ergebnisse im technischen Maßstab, wo aus dem Abwasser von 8600 Schweineplätzen und von 45000 Hühnern $2400 \mathrm{~m}^{3} / \mathrm{d}$ Faulgas mit einem Gesamtheizwert von $13,4 \times 10^{6} \mathrm{Kcal} / \mathrm{d}$ aus zwei Faulkammern von je $1000 \mathrm{~m}^{3}$ Inhalt wiedergewonnen werden konnte. Der CSB wurde bis zu 50-70\% abgebaut. Aus dem Gas wurde in Fiat-Motoren 127 Strom und Warmwasser erzeugt. Insgesamt gewinnt man $3960 \mathrm{kWh} / \mathrm{d}$, was wesentlich mehr ist als der Energie- und Wärmebedarf der Farm beträgt.

Das Abwasser wird in Hyazinthteichen nachgereinigt; diese Pflanzen werden ausgehoben und in einer Futtermischung verwertet.

\section{ВОЗМОЖНОСТИ ВОССТАНОВЛЕНИЯ ЭНЕРГИИ ВО ВРЕМЯ ОЧИСТКИ СТОЧНЫХ ВОД ОТ ВИНОКУРНОГО ЗАВОДА И ФЕРМ}

Приведены результаты опытных исследований в промышленном масштабе бескислородных выделенных камер ферментации (ВКФ) сточных вод от промышленных винокурных заводов и откормочных помещений свиней и птицеферм. Были отмечены хорошие эффекты понижения БПК 5 н ХПК (больше 90\%) при времени передержки ниже 10 суток (при применении рециркуляции осакда) 
для наиболее конщентрированных стоков. Особенно полезные эффекты в промышленном масштабе были получены для животноводческих ферм с 8600 стойлами свиней и 45000 кур, где созданная энергия составляла $13,4 \times 10^{6}$ ккал/сут., при производстве $2400 \mathrm{~m}^{3}$ газа/сут. со значением 5600 ккал $/ \mathrm{M}^{3}$ и поничжении ХПК 50-70\% в двух камерах ёмкостью каждой из них в $1000 \mathrm{M}^{3}$.

Для преобразования в электрическую энергию были применены двигатели автомобиля ФИАТ 127, приспособленные в вырабатыванию тока и горячей воды - получая 3960 кВтч/сут., что превышает суточную потребность всей фермы, а также энергию в виде теплоты. Дополнительная очистка сточных вод проводилась в лагунах с гиацинтами, которые затем мешались с кормом. 